\title{
$\delta$-Aminolevulinic acid dehydrase activity in the blood of men working with lead alkyls
}

\author{
J. A. MILLAR, G. G. THOMPSON, and A. GOLDBERG \\ MRC Research Group in Iron and Porphyrin Metabolism, Department of Materia Medica, \\ Stobhill General Hospital, Glasgow N.1
}

P. S. I. BARRY and E. H. LOWE

Associated Octel Company Limited, Ellesmere Port, Cheshire

\begin{abstract}
Millar, J. A., Thompson, G. G., Goldberg, A., Barry, P. S. I., and Lowe, E. H. (1972). Brit. J. industr. Med., 29, 317-320. $\delta$-Aminolevulinic acid dehydrase activity in the blood of men working with lead alkyls. The activity of erythrocyte $\mathrm{ALA}^{1}$-dehydrase is inhibited in vivo at blood lead $\left(\mathrm{Pb}^{2+}\right)$ levels within the upper range of normal $(20-40 \mu \mathrm{g} / 100 \mathrm{ml})$ and in vitro at lead concentrations greater than $10^{-7} \mathrm{M}$. In view of the high sensitivity of the enzyme to $\mathrm{Pb}^{2+}$, the levels of enzyme activity in the blood of men occupationally exposed to lead alkyls, particularly tetraethyllead, were measured. It was found that the enzyme activity in an exposed group of men was significantly less $(P<0.001)$ than in a control group, the respective mean values being 220 and 677 units of enzyme activity.

Tetraethyllead is metabolized in the body via triethyllead and diethyllead ions. As the latter compound possesses properties similar to $\mathrm{Pb}^{2+}$, it was synthesized in the laboratory and its effect on ALA-dehydrase was studied. Diethyllead ion was found to inhibit ALAdehydrase activity at concentrations greater than $5 \times 10^{-5} \mathrm{M}$, although the degree of inhibition was less than that obtained with $\mathrm{Pb}^{2+}$. These results suggest that exposure to tetraethyllead can cause a decrease in erythrocyte ALA-dehydrase activity.
\end{abstract}

Much attention has been given to the biochemical effects of lead in men occupationally exposed to the metal. The patterns of disordered porphyrin excretion are well known and have been related either to blood lead levels or to clinical symptoms (Gibson, Mackenzie, and Goldberg, 1968; Selander and Cramér, 1970). Lead as $\mathrm{Pb}^{2+}$ is known to produce increased porphyrin excretion by inhibiting the activity of several enzymes of haem biosynthesis, especially the second enzyme of the pathway, $\mathrm{ALA}^{1}$ dehydrase (E.C. 4.2.1.24). This enzyme catalyses the condensation of two molecules of ALA to give $\mathrm{PBG}^{2}$, the monopyrrolic precursor of haem. The

${ }^{1} \mathrm{ALA}=\delta$-aminolevulinic acid.

${ }^{2} \mathrm{PBG}=$ porphobilinogen. activity of this enzyme is apparently decreased in the blood of men occupationally exposed to $\mathbf{P b}^{2+}$ (Hernberg, Nikkanen, Mellin, and Lilius, 1970; Smith, Millar, and Goldberg, 1972) and in children (Millar et al., 1970; Giménez, Vallejo, Izurieta, and Singerman, 1970; Weissberg, Lipschutz, and Oski, 1971). The inhibitory effect of lead is such that the activity of the enzyme in vivo is decreased to below normal values at blood lead levels in excess of $20 \mu \mathrm{g} \%$ (Millar et al., 1970). In vitro a $20 \%$ inhibition is found at a lead concentration of $10^{-7}$ moles/ litre (Moore, 1970).

In view of the sensitivity of ALA-dehydrase to inorganic lead, it seemed of interest to measure the activity of the enzyme in the blood of men engaged in the manufacture of tetraethyllead, an organic 
compound of lead which is universally added to petroleum spirit in order to increase its octane rating. This compound is metabolized in the body to other complex ionic species of lead, namely triethyl- and diethyllead (Cremer, 1959), before a final probable degradation to $\mathrm{Pb}^{2+}$. Diethyllead, in particular, has several physicochemical properties similar to $\mathrm{Pb}^{2+}$, and the effect of this compound on ALA-dehydrase activity in vitro was measured.

\section{Materials and methods}

\section{Clinical data}

The study group (group 1) consisted of 27 employees of the Associated Octel Company Limited, who were engaged in the manufacture of tetraethyl- and tetramethyllead as operators (18 men), blenders (7) or maintenance engineers (2). Previous routine medical examination had shown that urinary lead levels were normal $(<50 \mu \mathrm{g} /$ litre $)$ in every case. The time period which had elapsed between the medical examination and the experiment was not more than eight weeks.

A control group (group 2) consisted of nine volunteers from the administrative staff of the same company. Urinary lead levels in these persons were measured at the time of the experiment and were also within the normal range.

The activity of ALA-dehydrase in the blood of the above two groups of persons was assayed and compared with the standard range of enzyme activity (419-625nM $\mathrm{PBG} / \mathrm{hr} / 10^{10}$ red cells) as measured in 20 normal persons (group 3) by the MRC group in Glasgow. As assays were performed in the Associated Octel Laboratories at Northwich, Cheshire, the enzyme activity in the blood of two members of group 3 was assayed with each batch of samples in order to detect any variations in measurement caused by differences in glassware, water hardness or other factors.

\section{Laboratory tests}

Blood was withdrawn by venepuncture and a $4-6 \mathrm{ml}$ aliquot for enzyme assay was placed immediately on ice. Blood lead was measured by the method of Bambach and Burkey (1942), as follows: After destruction of organic matter with nitric acid and ammonium sulphate, the residue was taken up with aqua regia. The mixture was rendered alkaline with ammonia, and citrate and cyanide were added. Lead was extracted using dithizone in chloroform. The organic extract was washed with phthalate buffer, $\mathrm{pH} 3 \cdot 4$, in order to separate bismuth which is also extracted at alkaline $\mathrm{pH}$. The lead was washed by this process into the aqueous phase. Reextraction of lead into the organic phase was accomplished as before, giving the red dithizonate which was estimated colorometrically at $516 \mathrm{~nm}$.

ALA-dehydrase was assayed by the method of Lichtman and Feldman (1963) as described by Moore, Beattie, Thompson, and Goldberg (1971). This technique involved incubation of the enzyme, prepared from red blood cells, with the substrate ALA. The quantity of PBG produced during 1 hour was then estimated colorimetrically using modified Ehrlich's reagent. Loss of PBG caused by activity of the subsequent enzyme of the pathway, PBGdeaminase, is negligible (Millar, unpublished observation). The activity of the enzyme was expressed in units of nmoles PBG produced $/ \mathrm{hr} / \mathbf{1 0}^{10}$ red cells. Urinary ALA was measured by the method of Mauzerall and Granick (1956).

Diethyllead dichloride was prepared by a two-stage synthetic route via tetraethyllead, as shown in Figure 1. The overall yield of diethyllead dichloride (m.p. 205$215^{\circ} \mathrm{C}$, lit. $207-220^{\circ}$ ) was $66 \%$ (lit. $68 \%$ ). The effect of this substance on human blood and rat liver ALAdehydrase activity was measured in vitro at $\left[\left(\mathrm{C}_{2} \mathrm{H}_{5}\right)_{2} \mathrm{~Pb}\right]^{2+}$ concentrations ranging from $10^{-3}$ to $10^{-7}$ Molar.

\section{Results}

\section{Blood lead}

The blood lead levels in the men engaged in tetraethyllead production (group 1) were significantly greater $(P<0.01$, Student's $t$ test $)$ than those found in the control group (Table). The mean values were 42.5 and $15 \mu \mathrm{g} \%$ respectively. However, none of the exposed men had a blood lead concentration greater than $80 \mu \mathrm{g} \%$, the level declared jointly by several authorities to be acceptable for occupationally exposed persons (British Medical Journal, 1968). (Note: $10^{-7} \mathrm{M} \mathrm{Pb}$ is equivalent to $20.7 \mu \mathrm{g} \%$.)

\section{ALA-dehydrase}

ALA-dehydrase activity in the blood of production workers (group 1) was significantly less $(\mathbf{P}<0.001)$ than the levels found in group 2 (Table). The mean activity in the latter group (677nM PBG/hr/10 10 red

\footnotetext{
Stage 1

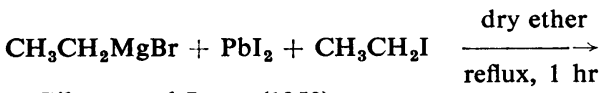

Reference: Gilman and Jones (1950) Reported yield of tetraethyllead $=85 \%$

\section{$\left(\mathrm{CH}_{3} \mathrm{CH}_{2}\right)_{4} \mathrm{~Pb}$}

tetraethyllead

Stage 2

solvent-toluene

$\left(\mathrm{CH}_{3} \mathrm{CH}_{2}\right)_{4} \mathrm{~Pb}+\mathrm{HCl}(\mathrm{g})$

Reference: Heap et al. (1951) $\mathrm{HCl}$ passed for $1 \mathrm{hr}$ reflux at $90^{\circ} \mathrm{C}$

$\left(\mathrm{CH}_{3} \mathrm{CH}_{2}\right)_{2} \mathrm{PbCl}_{2}$ diethyllead dichloride

FIG. 1. Laboratory synthesis of $\left(\mathrm{CH}_{3} \mathrm{CH}_{2}\right)_{2} \mathrm{PbCl}_{2}$. The equations are non-stoichiometric. 
TABLE 1

Blood LeAd $(\mu \mathrm{g} / 100 \mathrm{ml})$ AND ALA-DehydRASE (NM PBG/Hr/10 10 Red Cells) Levels in Men OCCUPATIONALly EXPOSED TO TETRAETHYLlead (GROUP 1), NON-EXPOSED WORKERS (GROUP 2), AND IN A REFERENCE NoRMal Group (Group 3) (Values are given as mean \pm SD. $\mathrm{P}$ values (Student's $t$ test) refer to differences between groups 1 and 2).

\begin{tabular}{|c|c|c|c|c|}
\hline & \multicolumn{3}{|c|}{ Group } & \multirow[b]{2}{*}{$\mathbf{P}$} \\
\hline & $\mathrm{n} \stackrel{1}{=} 27$ & $\mathrm{n} \stackrel{2}{=} 9$ & $\mathrm{n}=20$ & \\
\hline $\begin{array}{l}\text { ALA- } \\
\text { dehydrase } \\
\text { Lead }\end{array}$ & $\begin{array}{l}220 \pm 80 \\
42 \cdot 5 \pm 10\end{array}$ & $\begin{array}{c}677 \pm 230 \\
15 \pm 5\end{array}$ & $\begin{aligned} 522 & \pm 103 \\
28 & \pm 10\end{aligned}$ & $\begin{array}{l}<0.001 \\
<0.01\end{array}$ \\
\hline
\end{tabular}

cells) was not significantly different from the mean of the standard 'Glasgow' range (522nM PBG/hr/ $10^{10}$ red cells). No correlation was found between urine lead excretion and ALA-dehydrase activity in either group.

Urine ALA Urine ALA was within the normal range in every case (less than $0.57 \mathrm{mg} / 100 \mathrm{ml}$ ).

\section{Experimental study}

The effect of $\mathrm{Pb}^{2+}$ and $\left[\left(\mathrm{C}_{2} \mathrm{H}_{5}\right)_{2} \mathrm{~Pb}\right]^{2+}$ on ALAdehydrase activity was measured in vitro by adding each ion to the incubation mixture so that the final concentrations of each were $10^{-3}$ to $10^{-7} \mathrm{M}$. Figure 2 shows the relationship of each ionic species to enzyme activity. It can be seen that $\left[\left(\mathrm{C}_{2} \mathrm{H}_{5}\right)_{2} \mathrm{~Pb}\right]^{2+}$

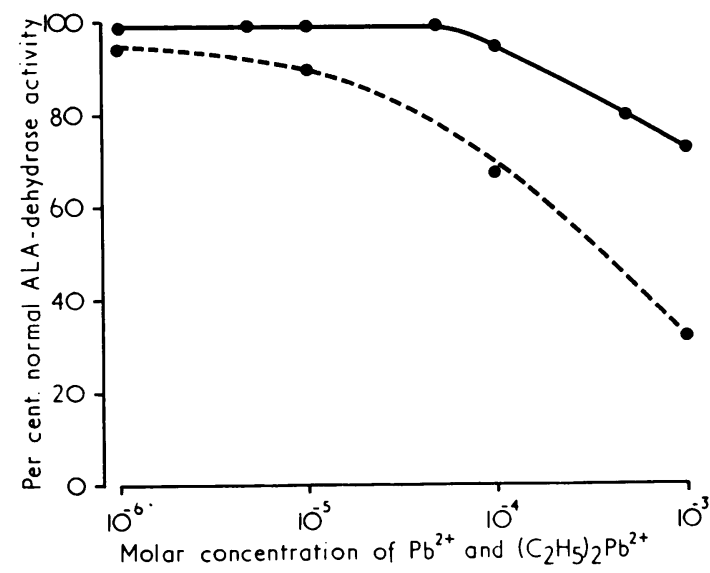

FIG. 2. Relationship between ALA-dehydrase activity and the ionic concentration of both $\mathrm{Pb}^{2+}$ (dotted line) and $\left[\left(\mathrm{C}_{2} \mathrm{H}_{5}\right)_{2} \mathrm{~Pb}\right]^{2+}$ (continuous line). does indeed have an inhibitory effect on ALAdehydrase at concentrations greater than $5 \times 10^{-5} \mathrm{M}$ although the degree of inhibition is less than that found with $\mathrm{Pb}^{2+}$.

\section{Discussion}

This study has shown that the activity of ALAdehydrase in the blood of men working in tetraethyllead production is significantly less $(P<0.001)$ than in control groups. None of the men with decreased ALA-dehydrase activity showed any clinical signs of plumbism, and urinary ALA excretion was normal in every case. These observations emphasize a property of lead-induced inhibition of ALA. dehydrase which has been noted in other subjects, namely, that a significant decrease in the activity of this enzyme in the blood occurs before any clinical or other biochemical signs of intoxication are apparent (Hernberg et al., 1970; Millar et al., 1970; Smith et al., 1972). Although ALA-dehydrase within the mature erythrocyte has no recognized function, a decrease in blood ALA-dehydrase activity is accompanied by a corresponding change in other organs, including those in which active haem synthesis occurs (Millar et al., 1970). These changes reflect the ability of each organ to accumulate lead, and may be predictable from the blood lead and ALA-dehydrase if an equilibrium situation is present (Millar, unpublished work). However, the longterm effect of decreased ALA-dehydrase activity on the integrity of the body's biochemistry has still to be assessed.

The immediate cause of the enzyme inhibition in group 1 is unlikely to be tetraethyllead itself, as this compound is insoluble in an aqueous medium. However, tetraethyllead undergoes hepatic transformation to triethyllead $\left[\left(\mathrm{C}_{2} \mathrm{H}_{5}\right)_{3} \mathrm{~Pb}\right]^{+}$, which is the most important neurotoxic agent of tetraethyllead poisoning (Cremer, 1959). This compound inhibits tissue respiration in brain cells in vitro at a concentration of $7 \times 10^{-7} \mathrm{M}$, probably by uncoupling oxidative phosphorylation in a similar manner to the analogous organotin compounds (Aldridge and Cremer, 1955; Cremer, 1957). This effect is insensitive to the addition of -SH groups (Cremer, 1959). Although triethyllead is relatively stable, significant levels of a further metabolite of tetraethyllead, namely diethyllead $\left[\left(\mathrm{C}_{2} \mathrm{H}_{5}\right)_{2} \mathrm{~Pb}\right]^{2+}$, appear within 24 hours in rats. Although this compound also inhibits brain cell oxygen uptake in vitro at a concentration of $10^{-5}$ $\mathrm{M}$, the effect can be reversed by adding -SH groups to the system (Cremer, 1959). It is also noteworthy that triethyl- and diethyllead produce different symptoms of toxicity in rats. Triethyllead causes excitability, tremors, and convulsions whereas diethyllead, like $\mathrm{Pb}^{2+}$, results only in a slight loss of weight (Cremer, 1959). Again, both tetraethyl- and 
triethyllead have potent sternutatory (sneeze producing) properties in man, whereas diethyllead is not sternutatory (Saunders and Stacey, 1949). In addition, $\mathrm{Pb}^{+2}$ and $\left(\mathrm{C}_{2} \mathrm{H}_{5}\right) \mathrm{Pb}^{2+}$ are both positively charged ions with a valency of 2 , whereas $\left(\mathrm{C}_{2} \mathrm{H}_{5}\right)_{4} \mathrm{~Pb}$ is neutral and $\left(\mathrm{C}_{2} \mathrm{H}_{5}\right)_{3} \mathrm{~Pb}^{+}$is univalent. All the above observations suggest that the biological and physicochemical properties of diethyllead are similar to $\mathrm{Pb}^{2+}$. It was for this reason that the effect of diethyllead on ALA-dehydrase was studied. The finding that this substance does have an inhibitory effect on ALA-dehydrase in vitro suggests that one effect of exposure to tetraethyllead will be a decrease in the activity of this enzyme in vivo, and is consistent with the possibility that the decreased enzyme activity found in the tetraethyllead workers was due to exposure to tetraethyllead. However, it is possible that exposure to the inorganic metallic lead and leadsodium alloy used as raw material (see appendix) is the major cause of the decreased activities.

The effect of other habits known to inhibit ALAdehydrase activity, in particular alcohol consumption (Moore et al., 1971) and cigarette smoking (Calandra, 1971), were not studied. Such habits may have had some influence on our findings among the group of workers investigated.

\section{References}

Aldridge, W. N., and Cremer, J. E. (1955). The biochemistry of organo-tin compounds. Biochem. J., 61, 406-418.

Bambach, K., and Burkey, R. E. (1942). Microdetermination of lead by dithizone. Industr. Engng Chem. Anal. ed., 14, 904-907.

British Medical Journal (1968). Diagnosis of inorganic lead poisoning; a statement. Brit. med. J., 4, 501.

Calandra, J. C. (1971). Statement before the Senate Transportation Committee of the State of California.

Cremer, J. E. (1957). The metabolism in vitro of tissue slices from rats given triethyltin compounds. Biochem. J., 67, 87-96.

(1959). Biochemical studies on the toxicity of tetraethyllead and other organo-lead compounds. Brit. J. industr. Med., 16, 191-199.

Gibson, S. L. M., Mackenzie, J. C., and Goldberg, A. (1968). The diagnosis of industrial lead poisoning. Brit. J. industr. Med., 25, 40-51.

Gilman, H., and Jones, R. G. (1950). Reactions of metallic thallium and metallic lead with organic halides. J. Amer. chem. Soc., 72, 1760-1761.

Giménez, E. R., Vallejo, N. E., Izurieta, M., and Singerman, A. (1970). Intoxicacion por plomo en pediatria. Rev. Assoc. bioquim argent., 35, 179-188.

Heap, R., Saunders, B. C., and Stacey, G. J. (1951). A new method for preparing diethyllead salts. J. chem. Soc., pp. 658-664.

Hernberg, S., Nikkanen, J., Mellin, G., and Lilius, H. (1970). $\delta$-aminolevulinic acid dehydrase as a measure of lead exposure. Arch. environm. Hlth, 21, 140-145.

Lichtman, H. C., and Feldman, F. (1963). In vitro pyrrole and porphyrin synthesis in lead poisoning and iron deficiency. $J$. clin. Invest., 42, 830-839.

Mauzerall, D., and Granick, S. (1956). The occurrence and determination of $\delta$-aminolevulinic acid and porphobilinogen in urine. J. biol. Chem., 219, 435-446.

Millar, J. A., Battistini, V., Cumming, R. L. C., Carswell, F., and Goldberg, A. (1970). Lead and $\delta$-aminolaevulinic acid dehydratase levels in mentally retarded children and in lead-poisoned suckling rats. Lancet, 2, 695-698.

Moore, M. R. (1970). Ph.D. thesis, University of Glasgow.

-, Beattie, A. D., Thompson, G. G., and Goldberg, A. (1971). Depression of $\delta$-aminolaevulic acid dehydrase activity by ethanol in man and rat. Clin. Sci., 40, 81-88.

Saunders, B. C., and Stacey, G. J. (1949). Organo-lead compounds. Part I. Trialkyl-lead salts possessing sternutatory properties. J. chem. Soc., pp. 919-925.

Selander, S., and Cramér, K. (1970). Interrelationships between lead in blood, lead in urine, and ALA in urine during lead work. Brit. J. industr. Med., 27, 28-39.

Smith, S. M., Millar, J. A., and Goldberg, A. (1972). Red cell $\delta$-aminolevulinic acid dehydrase activity in relation to other tests of lead toxicity. (In preparation.)

Weissberg, J. B., Lipschutz, F., and Oski, F. A. (1971). $\delta$-aminolaevulinic acid dehydratase activity in circulating blood cells. A sensitive laboratory test for the detection of childhood lead poisoning. New Eng!. J. Med., 284, 565-569.

\section{Appendix}

Tetraethyl and tetramethyl lead are manufactured at Ellesmere Port by the reaction of alkyl halide with a leadsodium alloy, as shown below. The lead is loosely bound with sodium to form a reactive alloy and three-quarters of the lead used in the process is recovered for further reaction.

Tetraethyllead: $4 \mathrm{C}_{2} \mathrm{H}_{5} \mathrm{Cl}+4 \mathrm{NaPb}$

$$
\rightarrow\left(\mathrm{C}_{2} \mathrm{H}_{5}\right)_{4} \mathrm{~Pb}+4 \mathrm{NaCl}+3 \mathrm{~Pb}
$$

Tetramethyllead: $4 \mathrm{CH}_{3} \mathrm{Cl}+4 \mathrm{NaPb}+$ catalyst

$$
\rightarrow\left(\mathrm{CH}_{3}\right)_{4} \mathrm{~Pb}+4 \mathrm{NaCl}+3 \mathrm{~Pb}
$$

Received for publication November 3, 1971. 